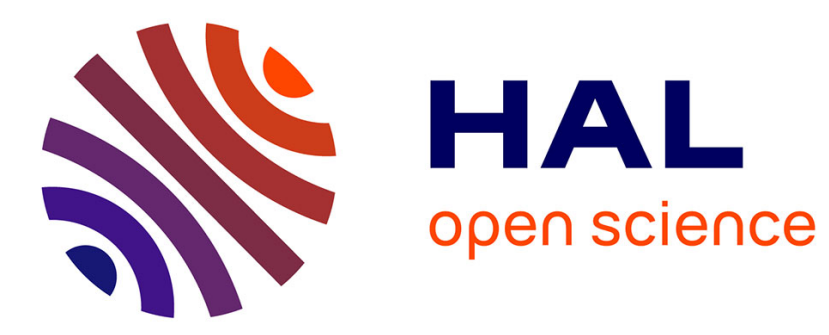

\title{
Innovative design for agriculture in the move towards sustainability: scientific challenges
}

Lorène Prost, Elsa T.A. Berthet, Marianne Cerf, Marie-Hélène Jeuffroy, Julie Labatut, Jean-Marc Meynard

\section{- To cite this version:}

Lorène Prost, Elsa T.A. Berthet, Marianne Cerf, Marie-Hélène Jeuffroy, Julie Labatut, et al.. Innovative design for agriculture in the move towards sustainability: scientific challenges. Research in Engineering Design, 2017, 28 (1), pp.119-129. 10.1007/s00163-016-0233-4 . hal-01337168

\section{HAL Id: hal-01337168 https://hal.science/hal-01337168}

Submitted on 24 Jun 2016

HAL is a multi-disciplinary open access archive for the deposit and dissemination of scientific research documents, whether they are published or not. The documents may come from teaching and research institutions in France or abroad, or from public or private research centers.
L'archive ouverte pluridisciplinaire HAL, est destinée au dépôt et à la diffusion de documents scientifiques de niveau recherche, publiés ou non, émanant des établissements d'enseignement et de recherche français ou étrangers, des laboratoires publics ou privés. 
Title: Innovative design for agriculture in the move towards sustainability: scientific challenges

Authors: Lorène Prost ${ }^{1}$, Elsa T.A. Berthet ${ }^{2,6}$, Marianne Cerf ${ }^{1}$, Marie-Hélène Jeuffroy ${ }^{3}$, Julie Labatut ${ }^{4,5}$, Jean-Marc Meynard ${ }^{2}$

1: UMR LISIS, INRA, CNRS, ESIEE Paris, UPEM, Université Paris-Est, F 77454 Marne-La-Vallée, France

2: UMR SADAPT, INRA, AgroParisTech, Université Paris-Saclay, F 78850 Thiverval-Grignon, France

3: UMR Agronomie, INRA, AgroParisTech, Université Paris-Saclay, F 78850 Thiverval-Grignon, France

4: INRA, UM R AGIR, Université de Toulouse, INPT ENSAT, F 31326 Castanet-Tolosan, France

5: MINES ParisTech, PSL Research University, Centre de Gestion Scientifique, F-75006 Paris, France

6: McGill University, Department of Natural Resource Sciences, H9X 3V9 Ste-Anne-de-Bellevue, Quebec, Canada

Corresponding author: Lorène Prost, INRA UMR LISIS, Batiment EGER, BP01, 78850 Thiverval-Grignon, France. lorene.prost@grignon.inra.fr

\begin{abstract}
:
Agriculture is facing increasing innovation challenges to meet current societal expectations, yet very few design science studies are devoted to it. This paper highlights some of the particularities of the objects, reasoning and organization of design in agriculture that may open fruitful scientific dialogue between design scientists and agricultural scientists. We first provide an overview of the broad range of objects that are designed in agriculture, and point out their specific characteristics with regard to design. We then identify some particular challenges of design activities in agriculture and review how they have been addressed up to now. Finally, we discuss how design challenges and characteristics in agriculture can contribute to current debate in the field of design science. We propose two main lines of inquiry and debate: enhancing the links between design reasoning and organization, and further conceptualizing the status of use situations in design to deal with uncertainties and complexity in design processes.
\end{abstract}

\title{
Keywords:
}

agriculture, farming systems design, innovative design, sustainability, design studies, design theory.

\section{Acknowledgements:}

We thank our two research divisions at INRA (French National Institute for Agricultural Research) for their support to the research on design in agriculture: the Science for Action and Development (SAD) division and the Environment \& Agronomy (EA) division. This work was realized on the initiative of the newly born INRA institute for design in agrifood systems.

We thank Liz Libbrecht for language editing the English version of this paper, and are deeply grateful to the three anonymous reviewers for their comments that were of great help for improving this article. 


\section{Introduction}

In Europe, a significant increase in agricultural productivity was essential after the Second World War, not only to achieve self-sufficiency in food, price reductions and food safety, but also to free up labor for industry. This momentum relied on an intensive and renewed design organization strongly supported by governments, which entrusted public and private research institutes with design activities related to agriculture. These institutes subsequently re-organized the relationships between research, development and production: they facilitated strong vertical organization, and externalized $R \& D$ from farms, putting extension services in charge of disseminating knowledge and ready-for-use practices to farmers. To reach its clearly defined objective of increasing agricultural production, this post-war design regime specifically aimed to control plant and animal growth processes and to lessen environmental hazards, in a strategy of confinement and artificialization that appeared possible with the development of synthetic inputs. For instance, plant production was achieved by using irrigation to decrease water stress, manufactured fertilizers to feed plants with sufficient nutrients, growth regulators to prevent lodging (plant bending), and pesticides to limit the occurrence and effects of diseases, pests and weeds. This trend was encouraged by the fact that knowledge was mostly produced in laboratories and experimental stations. M eanwhile, landscapes were homogenized through land consolidation to facilitate the use of large machines, and additionally by the reduction of domesticated biodiversity due to the farm specialization. In terms of productivity, this design regime was highly successful, as crop yields were multiplied by five in forty years (example of wheat in France; Brisson et al. 2010). However, this regime has been called into question for several decades now, and it has now been clearly established that intensive agriculture bears significant responsibility in the deterioration of the environment (water, soil and air pollution, biodiversity erosion, natural resource depletion, etc.) (M illenium Ecosystem Assessment 2005). Moreover, agriculture is facing new societal demands, related for instance to food safety, food quality, and non-food products. It also has to deal with the globalization of trade and to negotiate its new place in areas in which agricultural actors may play a marginal role (Meynard et al. 2012). Various scholars have stressed that agriculture should lessen its impacts on the environment by relinquishing its quest for environment control (Altieri, 2011). Alternative models of agriculture have emerged, drawing different lines of exploration such as precision farming based on farm automation, or agro-ecological farming (e.g., organic agriculture, conservation agriculture) taking advantage of in situ ecological and biological regulations. In any case, to move toward sustainability, agriculture faces a major challenge in its whole design regime, which has to shift from a rule-based design system toward an innovative design system (Le Masson et al. 2010; Meynard et al. 2012). The previous main objective of increasing production is nowadays enriched by new expectations; the identity (objectives, functions and performance criteria) of agricultural objects, such as crops, animal breeds, varieties, landscapes, machines or practices, has to be renewed; new techniques and strategies need to be designed; and the vertical design organization that prevailed in the past is called into question. Indeed, actors directly concerned by the consequences of agriculture, such as consumers or local authorities in charge of resource management, are now making their voices heard and wish to play a role in agriculture-related design. Moreover, reducing the standardization of agricultural practices requires that an increasing diversity of needs from numerous micro-entrepreneurs (the farmers) be addressed, for they act in widely diverse and poorly-controlled conditions and are embedded in various professional networks. This paper is intended to launch a fruitful interplay between the field of design science and the researchers aiming to support innovative design in the agricultural sector (irrespective of their discipline: agronomy, ecology, 
management, etc.). Although the theoretical ground of design in agriculture has been formalized based on agronomy and various social sciences, it has benefitted little from design sciences (Bos et al. 2009; Le Gal et al. 2011; Cerf et al. 2012; Meynard et al. 2012). This paper is an attempt to further develop this theoretical ground and to open the discussion to design studies and theories. We argue that because of its specificities, agriculture can contribute to developing design theories. In the following sections we first provide an overview of the objects that are designed in agriculture, and then focus on several characteristics and challenges of design engineering in agriculture. Finally, we discuss how design challenges and characteristics in agriculture could enrich current debates in the field of design science.

\section{What is designed in agriculture?}

What exactly is designed in agriculture is by no means evident, especially as agriculture deals with nature, which is often considered as given rather than designed. Although design studies have rarely focused on the economic sector of Agriculture, somewhat paradoxically, agriculture appears in seminal works of design science. At the beginning of his Sciences of the Artificial, Simon wrote: "A forest may be a phenomenon of nature; a farm certainly is not. The very species upon which we depend for our food, our corn, and our cattle are artifacts of our ingenuity. A plowed field is no more part of nature than an asphalted street and no less" (Simon, 1969, p.3). If we consider design as the process concerned with devising entities to attain goals, following Simon (ibid, p.114), then a wide diversity of objects can be considered as designed in agriculture (see the first column of Table 1), as they are built to attain explicit goals (e.g., productivity, resistance to pests or to water shortage, etc.).

\subsection{Description of the objects}

The first category of objects is quite specific to the agricultural sector as it is related to living entities and organisms. It encompasses plant varieties and animal breeds that correspond to populations which are methodologically developed to meet various specifications (Brancourt-Hulmel et al. 2003; Gauffreteau et al. 2014). For instance, the Holstein cow breed, known as "the milking machine" (Ruet 2004) is a breed that has been designed thanks to scientific methods of quantitative genetics with the main aim of maximizing milk production; MON 802 is an Insect Resistant maize variety designed and patented by the company Monsanto to eliminate the use of insecticides in maize fields. A second category of designed objects, although rarely recognized as such, is agricultural landscapes. These are arrangements of crops, grasslands and semi-natural elements (such as hedges) designed to fulfill given functionalities such as bird nesting, pollination, pest enemy enhancement, and consequently pesticide use reduction (Nassauer and Opdam 2008; Scherr and McNeely 2008). Combinations of farming practices, as production processes implemented to meet some specific goals and developed to control or enhance certain biological functions, are also designed. They encompass different operating systems in space and time. For instance, a cropping system is designed for a set of plots and combines a given crop succession over years (for instance, wheat in year 1, followed by barley in year 2, and then rapeseed in year 3) and the crop management plan applied to each of these different crops (Stockle et al. 2003; Debaeke et al. 2009). Agricultural implements and inputs are also designed. Finally, many decision support systems are designed (Cox 1996; M cCown 2002, Cerf et al, 2012) to help farmers and advisors (on nitrogen management, for example, see Li et al., 2009), or collectives of local actors (for instance, on prediction of harvest quality; see Le Bail et al. 2005) to adapt their decision to the diversity of soil and climate situations. 
Table 1: objects designed in agriculture: characteristics of design and current challenges

\begin{tabular}{|c|c|c|}
\hline $\begin{array}{l}\text { Designed } \\
\text { objects }\end{array}$ & $\begin{array}{l}\text { Characteristics of design engineering and identification } \\
\text { of the designers }\end{array}$ & Current challenges \\
\hline $\begin{array}{l}\text { Plant } \\
\text { variety }\end{array}$ & $\begin{array}{l}\text { Plant varieties are mostly designed by "plant breeders" } \\
\text { working for private companies. This is a long process that } \\
\text { takes about } 10 \text { years. Breeders cross-breed plants } \\
\text { according to specifications (for example highly productive } \\
\text { and highly disease-resistant and water-resistant, etc.) } \\
\text { which can be translated into required "traits". The design } \\
\text { process is a cycle of testing and sorting the "genotype": } \\
\text { every year they choose to keep only descendants that } \\
\text { combine the targeted traits. They observe their } \\
\text { performance in a range of agronomic situations and } \\
\text { sometimes various crop management plans that broaden } \\
\text { with time. Once stabilized, the genotype is tested through } \\
\text { formal regulatory procedures that have to be officially } \\
\text { registered. As the stage of official registration is } \\
\text { mandatory to access the market, its criteria strongly orient } \\
\text { the design of varieties (Lecomte et al. 2010). At EU level, } \\
\text { intellectual property of the varieties ensures recognition } \\
\text { of the private breeding companies' ownership of the } \\
\text { varieties they designed, but these varieties can } \\
\text { nevertheless be used and cross-bred by anyone else to } \\
\text { design other varieties. }\end{array}$ & $\begin{array}{l}\text { - Make the registration criteria and procedure } \\
\text { evolve within the existing strong legal } \\
\text { framework that attributes most value to the } \\
\text { productivity of the variety in order to meet } \\
\text { agro-ecological requirements. } \\
\text { The dominant design - the logic of which } \\
\text { underpins the current design of GM Os - is } \\
\text { challenged by: (i) demands for more } \\
\text { participatory breeding that re-introduces } \\
\text { farmers into the process (both in defining } \\
\text { breeding objectives and in selecting desired } \\
\text { varieties, variety mixture or populations of } \\
\text { plants) (Wolfe et al. 2008); and (ii) genomic } \\
\text { tools which are claimed to lead to higher gains } \\
\text { from breeding (Heffner et al. 2009). }\end{array}$ \\
\hline $\begin{array}{l}\text { Animal } \\
\text { breed }\end{array}$ & $\begin{array}{l}\text { Animal breeds (for example the Holstein breed or the } \\
\text { Limousine breed) are historically designed in cooperation } \\
\text { between farmers - who define the breeding objectives } \\
\text { and the breed's morphological criteria - and breeding } \\
\text { companies, with the help of scientists. The design of } \\
\text { animal breeds relies on genetic creation resulting from the } \\
\text { selection of the best animals according to specific } \\
\text { performance criteria, in order to produce new and } \\
\text { improved offspring. In the case of ruminants, animal } \\
\text { breeds' performance is evaluated on each farm through } \\
\text { on-farm recording by technicians from performance- } \\
\text { recording agencies, and through collective morphological } \\
\text { evaluation by farmers.. The idea is to determine the best } \\
\text { animals according to the criteria defined by farmers in the } \\
\text { farmers' association devoted to that breed. Data are then } \\
\text { transferred to a national information system, managed by } \\
\text { scientists, to calculate the genetic value of animals } \\
\text { through Estimated Breeding Values (EBVs, genetic } \\
\text { indexes). The best animals are then mated according to } \\
\text { their EBVs through artificial insemination or natural } \\
\text { mating to ensure the creation of genetic gain. Farmers } \\
\text { thus rear the next generation of breedinganimals (Labatut } \\
\text { et al. 2012) }\end{array}$ & $\begin{array}{l}\text { As regards plant varieties, there are currently } \\
\text { tensions between the design of limited- } \\
\text { number local breeds with participatory } \\
\text { approaches, and design processes that make } \\
\text { use of genomic approaches for developing } \\
\text { more sustainable animals (disease resistant, } \\
\text { feed efficient, etc.). }\end{array}$ \\
\hline $\begin{array}{l}\text { Cropping, } \\
\text { livestock or }\end{array}$ & $\begin{array}{l}\text { The combinations of farming practices aimed at } \\
\text { organizing crop or livestock production processes on }\end{array}$ & $\begin{array}{l}\text { - Improve the methods to design these } \\
\text { systems so that they encompass the }\end{array}$ \\
\hline
\end{tabular}




\begin{tabular}{|c|c|c|}
\hline $\begin{array}{l}\text { farming } \\
\text { systems }\end{array}$ & $\begin{array}{l}\text { farms are frequently designed by the farmers themselves, } \\
\text { with the support of technical adviso rs. For cropping } \\
\text { systems, this consists in choosing and planting the crops } \\
\text { successively in the field, and the techniques applied to } \\
\text { each one. While designed by the farmers, these systems } \\
\text { are influenced by their network (collective firms, input } \\
\text { seller, farmers networks enhan cing some practices such } \\
\text { as no tilling, etc.) and local or public policies (incentives } \\
\text { for the regulations to limit water pollution for instance). } \\
\text { As the interactions between techniques have heavy } \\
\text { consequences on field performance (Loyce et al. 2012), } \\
\text { they should be determined together, to produce a } \\
\text { coherent system (called cropping system for plant } \\
\text { production, livestock system for animal production). The } \\
\text { farming systems also involve manpower (and } \\
\text { management thereof) and investments in machinery, } \\
\text { required to reach the farmer's targets. }\end{array}$ & $\begin{array}{l}\text { numerous, and sometimes antagonistic, } \\
\text { issues existing today: field tests with a trial } \\
\text { and error approach, participatory processes, } \\
\text { use of modeling, or decision support tools } \\
\text { that could predict the multi-performance of } \\
\text { the practices before their implementation in } \\
\text { the field (M eynard et al. 2012). } \\
\\
\text { Two approaches co-exist: designing generic } \\
\text { systems (in the aim to transpose interesting } \\
\text { innovative systems, designed in a particular } \\
\text { locality, to a larger area) versus designing } \\
\text { site-specific systems (to make the best use of } \\
\text { local resources). }\end{array}$ \\
\hline Landscapes & $\begin{array}{l}\text { Agricultural landscape design is emerging as a promising } \\
\text { way to imp rove agriculture's sustainability. Indeed, many } \\
\text { ecological, hydrological and biogeochemical processes } \\
\text { occur at the landscape scale and are neglected when } \\
\text { design and management activities are led at the field or } \\
\text { farm scale. Common recommendations from ecologists } \\
\text { are for instance to maintain landscape heterogeneity } \\
\text { (Benton et al. 2003) in order to provide habitats for a } \\
\text { wider range of species, and/or connectivity (Taylor et al. } \\
\text { 1993) to facilitate species' dispersion. Such heterogeneity } \\
\text { and connectivity can be enhanced through the } \\
\text { localization and management of crops, semi-natural } \\
\text { elements and infrastructures (Rusch et al., 2010). The } \\
\text { design of sustainable agricultural landscapes, i.e. } \\
\text { producing a variety of ecosystem services, requires the } \\
\text { collaboration of a wide range of stakeholders (farmers, } \\
\text { extension services, local authorities, inhabitants, } \\
\text { researchers, etc.). }\end{array}$ & $\begin{array}{l}\text { - Produce more knowledge and concepts to } \\
\text { steer the design of agricultural landscapes, in } \\
\text { particular when the design cannot involve all } \\
\text { the actors concerned by a specific territory } \\
\text { (for instance a water catchment area } \\
\text { concerning hundreds of farmers). } \\
\text { - Solve the issue of identifying what can be } \\
\text { designed jointly and how, and then who } \\
\text { should contribute to the design process. A } \\
\text { priori there are no legitimate designers for } \\
\text { agricultural landscapes. } \\
\text { - Go further in the development of methods } \\
\text { and tools to support such complicated design } \\
\text { processes, such as scenarios, models and } \\
\text { participatory processes (see Berthet et al. } \\
\text { 2015) that involve long-term and large- scale } \\
\text { processes }\end{array}$ \\
\hline $\begin{array}{l}\text { Decision } \\
\text { support } \\
\text { systems } \\
\text { (DSS) }\end{array}$ & $\begin{array}{l}\text { Decision support tools, in particular those dedicated to } \\
\text { farmers to support crop management, are designed by } \\
\text { widely diverse actors such as cooperatives, applied or } \\
\text { public research institutes, and industries. They mostly } \\
\text { rely on agronomic scientific knowledge to produce } \\
\text { models, decision rules or indicators whose relevance, } \\
\text { robustness and reliability are tested. Such tools help to } \\
\text { adapt decision to the status of the soil-crop system: for } \\
\text { example, to calculate the rate of fertilizer to apply to } \\
\text { each field, or to decide whether a disease level on the } \\
\text { crop requires a fungicide application. }\end{array}$ & $\begin{array}{l}\text { - Ease the integration of the many biological, } \\
\text { chemical, physical and social processes that } \\
\text { interact, for instance by dealing with big data. } \\
\text { - Improve the efficiency and relevance of DSS. } \\
\text { In fact, in spite of numerous available } \\
\text { decision support tools, few of them are used } \\
\text { extensively and several authors link this } \\
\text { limited use to the poor involvement of users } \\
\text { in their design (M cCown 2002; Prost et al. } \\
\text { 2012; Cerf et al. 2012). }\end{array}$ \\
\hline $\begin{array}{l}\text { Agricultural } \\
\text { implements }\end{array}$ & $\begin{array}{l}\text { This dynamic sector includes the tractors themselves, the } \\
\text { agricultural implements or the machines that collect and } \\
\text { store digitized information about the environment } \\
\text { (sensors, drones, connected tools). Since the beginning of } \\
\text { the 20th century, industrial firms have generally taken on } \\
\text { their design and production. With the agro-ecology trend, }\end{array}$ & $\begin{array}{l}\text { - Develop connected devices and machines, } \\
\text { and manage the big data collected, even for an } \\
\text { autonomous agriculture. } \\
\text { - Increase the power of machines, in order to } \\
\text { decrease fuel consumption and preserve soils. }\end{array}$ \\
\hline
\end{tabular}




\begin{tabular}{|c|c|c|}
\hline & $\begin{array}{l}\text { many farmers design and adapt their own implements (for } \\
\text { example, to sow two different crops in different rows } \\
\text { simultaneously; or to apply a fertilizer or a herbicide only } \\
\text { on the sown row during the sowing). Simultaneously, } \\
\text { precision agriculture is another thriving trend for machine } \\
\text { design (for example, with the Real Time Kinematic } \\
\text { technology). }\end{array}$ & \\
\hline Inputs & $\begin{array}{l}\text { The chemical industry has been designing inputs } \\
\text { (fertilizers, pesticides, veterinary medicinal products) for } \\
\text { more than a century. The marketing authorization of } \\
\text { pesticides includes more and more demanding tests for } \\
\text { toxicity and eco-toxicity. Decreasing the use of inputs has } \\
\text { become a target in several countries with intensive } \\
\text { agriculture (France being one of them). In response to this } \\
\text { development, chemical firms are carrying out research on } \\
\text { biocontrol, i.e. the use of bio logical organisms, instead of } \\
\text { pesticides or veterinary chemical products, to control } \\
\text { pests and diseases. }\end{array}$ & $\begin{array}{l}\text { - Improve the proportion of fertilizer uptake by } \\
\text { plants (fertilizer use efficiency) or couple the } \\
\text { efficiency of pesticides with a better selectivity } \\
\text { of crops and biodiversity. } \\
\text { - Develop alternatives like biocontrol. } \\
\text { - Manage the use of pesticides and antibiotics, } \\
\text { in order to decrease the risks of resistance } \\
\text { breakdown. }\end{array}$ \\
\hline
\end{tabular}

\subsection{The key features of the agricultural objects impacting their design}

What are the key features of these objects impacting their design process?

First, the agricultural designed objects involve living entities that are managed: the plants, the crops, the soil micro-organisms, the fungi and insects that influence health and production. In fact, 'living entities' does not mean 'natural entities': since the beginning of agriculture, farmers have considerably shaped these entities to meet their own needs and purposes (through plant and animal breeding, for instance). The agricultural objects that are designed thus belong to an interesting category, somewhere between natural and artificial objects. Such living entities are managed throughout the year, and management processes, that are also designed, have to deal with the extensive regulations and feedbacks taking place within them.

Second, the agricultural designed objects are characterized by a strong variability and unpredictability. This is intrinsically due to the fact that the result of the implementation of agricultural techniques depends on the dynamics of living entities in environments that are themselves highly variable. Thus should we design objects that are satisfactory in widely diverse conditions (for instance, most cultivars developed today), or should we develop design processes that can better fit some local and specific environments (for example, landraces)? Variability and unpredictability thus become a decisive attribute of design processes in agriculture, and the philosophy underpinning such design is important: it determines the balance between a quest for control over the environment versus adaptive management (see Williams 2011), meaning monitoring biological balances under high uncertainty.

Third, these objects have a strong collective dimension stemming from the fact that the ideas, knowledge and principles underlying the objects, as well as the objects themselves, are less privatized than in other sectors, which strongly impacts their design: (i) the objects under design in agriculture are often common or public goods: for instance, animal breeds are the collective properties of farmers, and plant varieties are based on a 'private-like' property regime but as soon as they are registered, at least in the European Union, they can be used by other breeders to produce new varieties; (ii) agricultural practices impact public goods such as 
biodiversity or water quality, leading to the increasing influence of actors outside agriculture on the practices implemented in the fields, for example in the catchment areas (Ravier et al., 2015).

A fourth element arises as a consequence of these first three characteristics: the design processes of agricultural objects depend on heterogeneous forms of knowledge, which are needed not only to cope with unpredictability and to adjust to particular environments, but also to acknowledge the legitimacy of the broad range of actors connected to agricultural objects.

In the following part we will examine more closely these four challenges that agricultural designers have to face, and the solutions they devise to deal with them.

\section{Design in agriculture: challenges and solutions devised by agricultural designers}

\subsection{The design regime shift implies renewing the identity of the designed objects}

The post-war agricultural dominant design, intended to confine agricultural production and avo id environmental contingencies, oriented design processes towards a reduction of the scale of designed objects (for instance from a production system to a method of fertilization). Conversely, by seeking to balance agricultural production with the management of natural resources, one tends to reverse the process and to increase the scales and the number of inter-relations under consideration, or to tackle different scales together. Designing a set of farming practices often requires considering together the field scale, the farm constraints, the area in which the field is included (e.g. a water catchment area, or the collecting area of a cooperative) and the surrounding landscape composition (hedges, forest areas). For instance, solutions for oilseed rape protection against pollen beetle ( $M$ eligethes aeneus F.) can be designed at the field scale by adjusting insecticide treatments, or at the landscape scale by managing field localization to deal with wind-diffusion of pests from one field to another, or by managing forest edges to boost the populations of auxiliary insects that eat pollen beetles (Rusch et al. 2011). Likewise, widening the objectives of agricultural development and modernization requires changing the time scales under consideration, especially from short-run productivity objectives to long-term sustainability objectives. Some agronomic models exist that help to switch scales from the field to the landscape, from the day to the growing year (for instance Lô-Pelzer et al. 2010) but they only take on board part of the mechanisms involved. In fact, in a broader sense, addressing the environmental and health impacts of agriculture calls for systemic design approaches, in which designers take into account the complex interrelations and feedbacks between soil, plant, animal, weather and human practices. For instance, the use of pesticides on crops can threaten bee populations, thus pollination, which can have consequences on crop production. The current environmental crisis reveals that, contrary to the dominant design strategy, even if one needs to focus on the design of one subsystem, it is impossible to confine it and to ignore the whole system. Importantly, defining the scale and the limits of the objects under design is intrinsically meaningful, both strategically and politically. It will impact the monitoring and evaluation criteria of the designed object: each stakeholder will not evaluate a plant variety or a new cropping system with the same performance criteria. The chosen scale of design may exclude some actors and therefore the way of articulating agriculture with other activities. For instance, a cropping system directly concerns not only the farmer who implements it, but also the manager of the catchment area in 
which the field is located, as nitrogen and pesticide losses from the field may impact water quality. Several studies have then focused on the status of intermediary objects as a way to make this diversity visible in the design process (Gisclard et al. 2015).

\subsection{Design in agriculture requires renewing the way to address the diversity of environments}

Agricultural production is characterized by a huge diversity of soils, climates, available resources for each farm (area, material, manpower, cash, water, etc.) and market outlets. M ost agricultural systems or landscapes are therefore designed for one location, one farm, or one environment and differ from the ones designed elsewhere. Conversely, merchant innovations such as chemical inputs, decision support tools, or varieties are generally generic objects adapted to a large range of agricultural conditions. And some objects can be designed both from a local or a generic point of view: for example, cow breeds designed for world-wide diffusion (Holstein for instance) versus local breeds fitted to one region and specific livestock system (the Manex Black Sheep, a dairy sheep bred for mountainous areas in the Western Pyrenees; see Labatut et al. 2012). Actually, the two approaches are often intertwined but both call for design methods that allow the designers to deal with this environmental diversity.

The design process to build generic objects has long been based on the assumption that variability can be reduced by artificializing the environments of crops or cattle, by using inputs and processes of confinement (hydroponic horticulture, industrial poultry farms). It is also based on the use of specific methods to assess the objects under design. For example, breeders use multi-environment trials, carried out on several locations and for several years, to compare their new varieties with current varieties (Lecomte et al. 2010): only the new varieties that perform well under a wide range of conditions are kept. This type of procedure, which also exists for plant protection products, aims at designing objects with a broad spectrum of use.

To design locally-adapted cropping or livestock systems, agronomists now distinguish two families of methods (Meynard et al. 2012). The first one, called de novo design, aims at building prototypes to find a breakthrough in comparison with present systems. Design workshop methods (Vereijken 1997; Bos et al. 2009; Reau et al. 2012) are proposed to organize such exploration by highlighting the complementarity of actors (farmers, advisors, environmentalists, actors from the markets, local political actors, researchers, experts, etc.). Agronomic models are also frequently used to design such prototypes and to facilitate the exploration of a large number of solutions and their effects in the short and long term (e.g. Bergez et al. 2010). In de novo design the focus is however on the target to reach and not on the process necessary to reach this target, whereas several agronomists see the management of the transition from present to future as an important part of the design process. They argue that it should therefore be better understood and equipped (Toffolini et al. 2016). That is why agronomists have proposed the concept of step by step design (M eynard et al. 2012), to underline the processes leading from the current situations to the desired ones (Chantre and Cardona, 2014). An existing system is taken as a starting point and gradually improved and turned into another system that was not predefined in terms of its physical and operational characteristics, but of which main functionalities and drivers had been identified at the beginning of the design process. Several loops, over many years, are meant to enable the design of the new system and the learning of the relevant cues that support its management (Coquil et al. 2014; Chantre et al. 2015). That type of method produces very particular and local design solutions. 
The diversity of conditions in agriculture may be seen as a cost for design processes but it is also a source of innovative ideas. Cerf and M eynard (2006) have shown that specific situations are conducive to the emergence of innovative concepts that may then be useful in other situations. They give the example of a simplified method to calculate fertilizer rates, designed for wheat grown in shallow and stony soils where the conventional method is not feasible. This method then proved to be efficient for other crops and in other environments, and is still frequently used in France today. Therefore agronomists now develop methods to seek innovative concepts and innovative use of existing artifacts in order to open the range of design solutions.

All the methods discussed in this section were also developed to fit the way in which design processes have been organized in agriculture. A challenge is to adjust them in line with changes in this organization. But who designs? How are people organized from research to production?

\subsection{Design in agriculture is increasingly collective and distributed}

As explained in the Introduction, the post-war design regime and its strong vertical organization distributed design processes among several actors. Today's need for an innovative design system is however renewing the collective nature of agricultural design processes: the actors that take part in design processes as well as the arenas in which design processes can take place.

First, the range of actors who can legitimately take part in design is increasing, and the role of some historical actors is changing. For example, farmers are once again considered more and more as designers of their own production systems, and advisors are no longer expected to provide turnkey solutions applicable across the board. Additionally, new actors are asking to be involved in design processes, such as consumers, NGOs, local authorities, etc. (Bos et al. 2009). New arenas have been created to make it possible for them to express their opinions, and to contribute to the targets and evaluation of potential solutions (see Ravier et al. 2015, for the design of cropping systems in water catchment areas; Etienne 2014, on several cases for designing the governance of resources). This is evidenced in new policy instruments such as local deliberative arenas created to meet specific environmental issues defined in European directives (nitrogen, water quality, biodiversity). But there is still a challenge to transform these consultative arenas into effective design arenas. And sometimes the relevant arenas with the relevant design actors do not even exist and have to be built. That is our second point: new design organizations have to be developed. New collective design methods are required to involve not only research centres and extension services but more widely a variety of actors with heterogeneous knowledge and interests. Berthet et al. (2015), comparing three collective design methods to foster agroecology, show that the "agro-ecological turn calls for participatory design methods that are not only decisionmaking support tools but also ways of fostering exploration of new solutions in situations where objectives and performance criteria are unknown and where generic responses are not appropriate". Such an exploration process requires designing both the object (e.g., a sustainable agricultural landscape) and the governance rules for managing the object in the long run. For example, in the west of France, a new process for landscape design (Berthet et al. 2012; Berthet 2014) was recently explored for the preservation of the Little Bustard (Tetrax tetrax), a European bird species threatened by habitat loss and food scarcity. To maintain food availability for this species, the solution identified by ecologists was to control the distribution of grasslands (considered as insect populations' regeneration areas) throughout the cereal plain. A design process involving various local stakeholders (farmers, ecologists, agronomists, local authorities, etc.) was initiated to build a multifunctional landscape. However, they encountered a difficulty insofar as designing new landscapes requires the renewal of 
territo rial actors' conventional roles. In this example, the objective was to entrust an agricultural cooperative, supported by researchers in ecology, to implement the grassland matrix. This nevertheless posed various problems such as vision sharing and legitimacy for the cooperative to assume its new role. The renewal of agricultural organizations' identity so that they can take environmental issues into account more adequately is still facing strong lock-ins.

\subsection{Design in agriculture increasingly requires the articulation of heterogeneous forms of knowledge}

In the agricultural sector, the knowledge that feeds design processes is hybridized. For a long time this knowledge was practice-based, as each farmer increased his/her knowledge by learning from what happened in his/her own fields. Then, with the development of agronomy as a science, it tended to become more sciencebased and more generic: experiments and modeling revealed the biological mechanisms of plants, the soil, the atmosphere and their interactions. But 'non-scientific' types of knowledge (whether they be called traditional, expert, empirical, or lay) are still needed in design processes, because the expression of biological regulation and interactions in specific local conditions is still poorly known (Doré et al. 2011; Malézieux 2012), and because the knowledge produced through the use of designed objects is largely implicit yet fully relevant (Altieri 1989). This strongly revives the issue of combining heterogeneous types of knowledge in design processes. Agronomists have tackled this issue by trying to make this local knowledge explicit and by working on methods that help to combine different types of knowledge to produce innovative local solutions (Walker et al. 1999; Soulignac et al. 2012; Girard 2015). The challenge for both agricultural science and design science is to prove that this hybridization catalyzes both design processes and knowledge production: heterogeneous sources of knowledge can be combined to produce new knowledge thanks to design processes. To illustrate this idea, consider the design of a decision support tool. Researchers first undertook an analysis of the activities of potential users (Lecomte et al., 2010). They then developed Diagvar, a prototype of a tool that supports the characterization of winter wheat cultivars to identify those best suited to specific agronomic situations. Users tested the prototype on a range of their own recent datasets to stick as closely as possible to their work situations. They pointed out several issues regarding the decision tool, and discussed the assumptions made in the agronomic model on which the tool was based. This dialogue among users and designers raised new research questions for which the researchers developed new agronomic and statistical knowledge (Prost and Jeuffroy 2007; Prost et al. 2008). Thus, the users' involvement not only confronted the tool with their practices; it also validated the knowledge they built in the course of their work. In parallel, use of the tool obliged the designers to open the 'black box' of the tool, which made their knowledge visible. This dual visibilization generated controversies on the model and resulted in the exploration of new knowledge (Béguin et al. 2012).

\section{Discussion \& Perspectives}

As agriculture needs to undergo profound transformation in order to achieve sustainability, it is necessary to renew all the design organizations, tools and methods involved, as well as the views and concepts underlying them. Such a transformation across the board requires strong theoretical support, as Le Masson et al. (2013) has pointed out :"each engineering revolution (e.g. chemical, electrical, electronics, or software) was accompanied by the development of its own appropriate design tools and theories". This paper outlines several challenges and characteristics of design in agriculture and how scholars in the field have dealt with them. It proposes the 
development of an empirical design theory for an agricultural world in search of innovation, drawing upon previous research studies that mobilize the C-K theory, for instance (see Berthet et al. 2012; Cerf et al. 2012). Looking at design processes in agriculture through the framework of design science would clearly be an asset to research and development in agriculture. It would allow agricultural designers to analyze their empirical propositions in the light of the existing design theories, in line with what Reich et al. (2012) and Kroll et al. (2014) have called 'theory-driven' or 'theory-based' analysis.

In return, what can the agricultural case contribute to debate on design theories? Agriculture is a field where formal models and theories of design can be tested, illustrating that "research in design theory should be anchored in an interplay between formal models and empirical studies" (Le Masson et al. 2013). We argue that it is important for design sciences to address the specific objects and design challenges of agriculture, in order to enrich its theories and develop new methods and tools. To this end, we raise two points for discussion.

Our first point relates to the fact that formal design theories have focused on design reasoning at the expense of organizational issues. Hatchuel et al. (2003) acknowledge this issue: "For sure, Design is not only a mode of reasoning. It is also a human collective process shaped by history, culture, and social or organizational norms. Yet, these two perspectives on design are not independent [...]. A comprehensive view of design should address both aspects ". We argue that the highly collective and distributed design processes in agriculture revive the interdependence between reasoning and organization, especially nowadays, as the challenges of sustainability have led new actors to become involved in steering the future trajectory of agriculture. As agricultural design needs to broaden its range of objectives, scales and designers, new design arenas are emerging, in which diverging interests have to be taken into account. It is therefore important to clarify ways in which to manage design processes involving a range of organizations and/or actors whose interests can initially diverge. Actually, in collective design processes it is not only an object that is designed but also the activities of all those who take part in the design, and any choices related to what these activities may be in the future (Robertson and Simonsen 2012). As Bjögvinsson et al. (2012) put it, 'a fundamental challenge for designers and the design community is to move from designing "things" (objects) to designing Things (socio-material assemblies)', and this should appear in design theories. Such research endeavours could draw upon Segrestin (2006)'s work on "exploratory partnerships", i.e., new forms of inter-firm cooperation aiming to explore opportunities for innovation while simultaneously managing coordination and cohesion, or Le Masson et al. (2012)'s study of "colleges of the unknown", i.e. organizations set up by innovation ecosystems to explore emerging technologies and to build roadmaps for the future. Likewise, the agricultural sector has to invent new organizations and institutions facilitating the involvement of a variety of actors - including farmers - in the exploration of innovations increasingly oriented toward agriculture's sustainability. Agriculture may then prove to be a fruitful domain to further articulate theories focused on design reasoning, with those related to design management.

The second point is related to the fact that agricultural objects are at the interface between the natural and the artificial, between living entities and management processes. As M argolin (1995) puts it, 'to the degree that design makes incursions into realms that were once considered as belonging to nature rather than culture, so does the conceptual scope of design practice widen'. Studying agriculture-related objects through the lens of design theories can then be a way to take part in the debates about the nature of design (see for instance Love, 2002 or Hatchuel et al. 2013). Indeed, the fact that agricultural design needs to re-incorporate ecological processes and feedbacks brings to the fore the issues of complexity and unpredictability that the agricultural 
sector's previous design strategies tended to minimize. And these issues of complexity and unpredictability, and of knowledge voids or holes, are of prime importance in design and design theories. Le Masson and Weil (2013) state that 'while engineering sciences model known objects, design theories support reasoning on unknown objects'. Recent design theories rely on the identification of knowledge voids or holes as drivers of creativity, such as the C-K theory (Hatchuel et al. 2013) or Infused Design as explained by Shai et al. (2013). They also focus on the mechanisms that allow an exploration of a part of this unknown. Hatchuel et al. (2013) state that "the rationality of design keeps the logic of intention but accepts the undecidability of its target; it aims at exploring the unknown, and it is adapted to the exploitation of the emergent." This applies fully to situations where local actors need to design a sustainable agricultural landscape: the goals are not pre-identified and not all design parameters are controllable. In fact, in agriculture the part of irreducible unknowns is huge, not only because of its dependence on climatic factors, but also because of the complexity and the multiplicity of the mechanisms at work in agriculture (from biological to social ones). As Roberts (2013) states: it has un-knowable 'known unknown' that drives design but also challenges it. It emphasizes the necessity of dealing with uncertainty and complexity in design, a subject on which various scholars in design sciences propose methods and models (Suh 1999; Crossland et al. 2003; Ameri et al. 2008). For instance, Axiomatic Design (Suh 1990) is helpful in dealing with such complexity as it provides a mapping, first of the design process that identifies the functional requirements (FRs) that will specify the customers' needs, and second of the design parameters (DPs) that will satisfy the functional requirements. Suh put forward two axioms, the Independence Axiom (maintain independence of FRs) and the Information Axiom (minimize the information content of the design) to help designers make relevant decisions about design alternatives, by enhancing the stability and the controllability of designed systems. However, in a context where coupling between DPs and FRs is increasingly acknowledged, the application of this theory to the design of agricultural systems is challenging: as agro-ecological processes are highly interconnected and modularity is generally impossible, the matrix resulting from the successive mapping processes will systematically be incomplete. We think that a way to manage uncertainty would be to bring 'use situations' into design as they integrate the ways in which actors act under uncertainty. How? In our opinion, use situations cannot easily be 'described' as they are not reducible to pieces of knowledge (see also Brown 2013: 24-30). M ethodological propositions for instance have been put forward to this end, promoting a way to build a diagnosis of uses and to foster interactions with users around prototype tools, based on the characteristics of their work situations and the assumptions about how they could use the tools, identified during the diagnosis (Cerf et al. 2012). We could go a step further and consider that it is necessary not only to incorporate the use situations in design processes but also to design them at the same time as the object itself. This idea would deserve to be further explored in interaction with design theories.

\section{Conclusion}

This paper provided some examples of the challenges that design in agriculture is dealing with and the ways in which current research is addressing them. It also discussed the current interactions between agriculture and design, showing how design theories could enrich analyses on agriculture, and how this specific engineering field may challenge the theories and call for further research in design science, more specifically on the articulation between design reasoning and organization, and on ways to manage uncertainty, unknowables and complexity in design. It is above all an invitation to enliven interplay between the agricultural designers who want to improve their practices and their theoretical work on those practices, and all the researchers interested in 
Design Science and Design Studies. Through their particularities, the design processes in agriculture have the ability to enrich, support and challenge these fields. Future research could benefit from collaborating with design researchers in this exciting work.

\section{Bibliography}

Altieri M A (1989) Agroecology: A new research and development paradigm for world agriculture. Agric Ecosyst Environ 27:37-46. doi: 10.1016/0167-8809(89)90070-4

Altieri M A, Funes-M onzote FR and Petersen P (2011) Agroecologically efficient agricultural systems for smallholder farmers: contributions to food sovereignty. Agron Sustain Dev 31:1-13. doi 10.1007/s13593-011-0065-6

Ameri F, Summers JD, M ocko GM and Porter M (2008) Engineering design complexity: an investigation of methods and measures. Res Eng Des 19:161-179.

Béguin $P$, Cerf $M$ and Prost $L$ (2012) Co-design as an emerging distributed dialogical process between users and designers. In: Barbier M , Elzen B (ed) System Innovations, Knowledge Regimes, and Design Practices towards Transitions for Sustainable Agriculture, INRA Editions [online], URL: http://www4.inra.fr/sad_eng/Publications2/Free-e-books/SystemInnovations-for-Sustainable-Agriculture, pp 154-170.

Benton TG, Vickery JA and Wilson JD (2003) Farmland biodiversity: is habitat heterogeneity the key? Trends Ecol Evol 18(4): 182-188.

Bergez JE, Colbach N, Crespo O, Garcia F, Jeuffroy M H, Justes E, Loyce C, M unier-Jolain N and Sadok W (2010) Designing crop management systems by simulation. Eur J Agron 32:3-9.

Berthet ETA (2014) Concevoir l'écosystème, un nouveau défi pour l'agriculture (Designing the ecosystem: a new challenge for agriculture). Presse des Mines, Paris

Berthet ETA, Barnaud C, Girard N, Labatut J and Martin G (2015) How to foster agroecological innovations? A comparison of participatory design methods. J Environ Plan Manag. doi:10.1080/09640568.2015.1009627

Berthet ETA, Bretagnolle V, Segrestin B (2012) Analyzing the Design Process of Farming Practices Ensuring Little Bustard Conservation: Lessons for Collective Landscape Management. J Sustain Agric 36:319-336. doi: $10.1080 / 10440046.2011 .627988$

Bjögvinsson E, Ehn P and Hillgren P-A (2012) Design things and design thinking: Contemporary participatory design challenges. Des Issues 28:101-116.

Bos AP, Groot Koerkamp PWG, Gosselink JMJ and Bokma S (2009) Reflexive interactive design and its application in a project on sustainable dairy husbandry systems. Outlook Agric 38:137-145.

Brancourt-Hulmel M, Doussinault G, Lecomte C, Bérard P, Le Buanec B and Trottet M (2003) Genetic Improvement of Agronomic Traits of Winter Wheat Cultivars Released in France from 1946 to 1992. Crop Sci 43:37. doi:

$10.2135 /$ cropsci2003.3700

Brisson N, Gate P, Gouache D, et al (2010) Why are wheat yields stagnating in Europe? A comprehensive data analysis for France. Field Crops Res 119:201-212.

Brown I (2013) Entre firme et usagers : des biens génératifs d'usages.Théorie des biens comme espaces de conception. Paris, ENM P

Cerf M, Jeuffroy M-H, Prost L and M eynard J-M (2012) Participatory design of agricultural decision support tools: taking account of the use situations. Agron Sustain Dev 32:899-910. doi: 10.1007/s13593-012-0091-z

Cerf $M$ and M eynard J-M (2006) Les outils de pilotage des cultures: diversité de leurs usages et enseignements pour leur conception. Nat Sci Sociétés 14:19-29.

Chantre E, Cardona A (2014) Trajectories of French field crop farmers moving toward sustainable farming practices: Change, learning, and links with the advisory services. Agroecol Sustain Food Syst 38:573-602.

Chantre E, Cerf M and Le Bail M (2015) Transitional pathways towards input reduction on French field crop farms. Int J Agric Sustain 13:69-86. doi: 10.1080/14735903.2014.945316

Coquil X, Beguin P and Dedieu B (2014) Transition to self-sufficient mixed crop-dairy farming systems. Renew Agric Food Syst 29:195-205. doi: 10.1017/S1742170513000458 
Cox PG (1996) Some issues in the design of agricultural decision support systems. Agric Syst 52:355-381. doi: 10.1016/0308$521 \times(96) 00063-7$

Crossland R, dapti JHS and M CM ahon CA (2003) An object-oriented modeling framework for representing uncertainty in early variant design. Res Eng Des 14:173-183.

Debaeke P, Munier-Jolain N, Bertrand M, Guichard L, Nolot J-M , Faloya V and Saulas P (2009) Iterative Design and Evaluation of Rule-Based Cropping Systems: M ethodology and Case Studies-A Review. Agron Sustain Dev 29 (1):73-86. doi:10.1051/agro:2008050

Doré T, Makowski D, M alézieux E, Munier-Jolain N, Tchamitchian M and Tittonell P (2011) Facing up to the paradigm of ecological intensification in agronomy: revisiting methods, concepts and knowledge. Eur J Agron 34:197-210.

Étienne M (ed) (2014) Companion M odelling. Springer Netherlands, Dordrecht

Gauffreteau A, Charmet G, Jeuffroy M-H, Le Gouy J, M eynard J-M and Rolland B (2014) Variétés et itinéraires techniques du blé : une évolution vers la diversification. Agron Environ Sociétés 4:13-22.

Girard N (2015) Knowledge at the boundary between science and society: a review of the use of farmers' knowledge in agricultural development. J. Knowl. Manag. 19(5): 949-967

Gisclard M , Chantre É, Cerf M , Guichard L (2015) Co-click'eau: une démarche d'intermédiation pour la construction d'une action collective locale? Nat Sci Sociétés 23:3-13.

Hatchuel A, Weil B and Le Masson P (2013) Towards an ontology of design: lessons from C-K design theory and Forcing. Res Eng Des 24:147-163.

Hatchuel A, Weil B and others (2003) A new approach of innovative Design: an introduction to CK theory. DS 31:

Proceedings of ICED 03, the 14th International Conference on Engineering Design, Stockholm

Heffner EL, Sorrells M E and Jannink J-L (2009) Genomic Selection for Crop Improvement. Crop Sci 49:1-12. doi: $10.2135 /$ cropsci2008.08.0512

Kroll E, Le Masson P and Weil B (2014) Steepest-first exploration with learning-based path evaluation: uncovering the design strategy of parameter analysis with C-K theory. Res Eng Des 25:351-373. doi: 10.1007/ s00163-014-0182-8

Labatut J, Aggeri F and Girard N (2012) Discipline and Change: How Technologies and Organ izational Routines Interact in New Practice Creation. Organ Stud 33:39-69. doi: 10.1177/0170840611430589

Le Bail M, Jeuffroy M H, Bouchard C and Barbottin A (2005) Is it possible to forecast the grain quality and yield of different varieties of winter wheat from M inolta SPAD meter measurements? Eur J Agron 23:379-391. doi:

10.1016/j.eja.2005.02.003

Lecomte C, Prost L, Cerf M and M eynard J-M (2010) Basis for designing a tool to evaluate new cultivars. Agron Sustain Dev 30:667-677. doi: 10.1051/agro/2009042

Le Gal P-Y, Dugué P, Faure G and Novak S (2011) How does research address the design of innovative agricultural production systems at the farm level? A review. Agric Syst 104:714-728.

Le M asson P, Weil B and Hatchuel A (2010). Strategic M anagement of Design and Innovation, Cambridge University Press, Cambridge.

Le M asson P, Weil B, Hatchuel A and Cogez P (2012). Why aren't they Locked in Waiting Games? Unlocking Rules and the Ecology of Concepts in the Semiconductor Industry. Technol Anal Strateg 24 (6):617-630.

Le M asson P, Dorst K and Subrahmanian E (2013) Design theory: history, state of the art and advancements. Res Eng Des 24:97-103.

Le M asson P and Weil B (2013) Design theories as languages of the unknown: insights from the German roots of systematic design (1840-1960). Res Eng Des 24:105-126.

Li FY, Johnstone PR, Pearson A, Fletcher A, Jamieson PD, Brown HE and Zyskowski RF (2009) AmaizeN: A decision support system for optimizing nitrogen management of maize. NJAS - Wagening J Life Sci 57:93-100. doi:

10.1016/j.njas.2009.07.007

Lô-Pelzer E, Bousset L, Jeuffroy MH, et al (2010) SIPPOM -WOSR: A Simulator for Integrated Pathogen POpulation Management of phoma stem canker on Winter OilSeed Rape: I. Description of the model. Field Crops Res 118:73-81. doi: 10.1016/j.fcr.2010.04.007 
Love T (2002) Constructing a coherent cross-disciplinary body of theory about designing and designs: some philosophical issues. Des Stud 23:345-361.

Loyce C, M eynard JM , Bouchard C, Rolland B, Lonnet P, Bataillon P, Bernicot M H, Bonnefoy M, Charrier X, Debote B et al. (2012) Growing winter wheat cultivars under different management intensities in France: A multicriteria assessment based on economic, energetic and environmental indicators. Field Crops Res 125:167-178. doi: 10.1016/j.fcr.2011.08.007

Malézieux E (2012) Designing cropping systems from nature. Agron Sustain Dev 32:15-29.

Margolin V (1995) The politics of the artificial. Leonardo 349-356.

M cCown RL (2002) Changing systems for supporting farmers' decisions: problems, paradigms, and prospects. Agric Syst 74:179-220. doi: 10.1016/S0308-521X(02)00026-4

M eynard J-M, Dedieu B and Bos B (2012) Re-design and co-design of farming systems. An overview of methods and practices. In: Darnhofer I, Gibbon D and Dedieu B (eds) Farming Systems Research into the 21st Century: The New Dynamic. Springer Netherlands, pp 405-429

Millenium Ecosystem Assessment (2005) Ecosystems and human well-being. Island Press Washington, DC Nassauer JI and Opdam P (2008) Design in science: extending the landscape ecology paradigm. Landsc Ecol 23:633-644. Prost L, Cerf M and Jeuffroy M-H (2012) Lack of consideration for end-users during the design of agronomic models. A review. Agron Sustain Dev 32:581-594. doi: 10.1007/s13593-011-0059-4

Prost $\mathrm{L}$ and Jeuffroy M -H (2007) Replacing the nitrogen nutrition index by the chlorophyll meter to assess wheat $\mathrm{N}$ status. Agron Sustain Dev 27:321-330. doi: 10.1051/agro:2007032

Prost L, M akowski D and Jeuffroy M -H (2008) Comparison of stepwise selection and Bayesian model averaging for yield gap analysis. Ecol Model 219:66-76. doi: 10.1016/j.ecolmodel.2008.07.026

Ravier C, Prost L, Jeuffroy M-H, Wezel A, Paravano L and Reau R (2015) Multi-criteria and multi-stakeholder assessment of cropping systems for a result-oriented water quality preservation action programme. Land Use Policy 42:131-140. doi: 10.1016/j.landusepol.2014.07.006

Reau R, M onnot L-A, Schaub A, M unier-Jolain N, Pambou I, Bockstaller C, Cariolle M, Chabert A and Dumans P (2012) Les ateliers de conception de systèmes de culture pour construire, évaluer et identifier des prototypes prometteurs. Innov Agron 20:5-33.

Reich Y, Hatchuel A, Shai $O$ and Subrahmanian E (2012) A theoretical analysis of creativity methods in engineering design: casting and improving ASIT within C-K theory. J Eng Des 23:137-158. doi: 10.1080/09544828.2010.493505

RobertsJ (2013) Organizational igno rance: Towards a managerial perspective on the unknown. Manag Learn 44:215-236. doi: 10.1177/1350507612443208

Robertson T and Simonsen J (2012) Challenges and opportunities in contemporary participatory design. Des Issues 28:3-9. Ruet $F(2004)$. De la vache machine en élevage laitier. Quaderni 56: 59-69.

Rusch A, Valantin-M orison M, Sarthou J-P, et al (2010) Biological Control of Insect Pests in Agroeco systems: Effects of Crop M anagement, Farming Systems, and Seminatural Habitats at the Landscape Scale: A Review. Adv Agron 109:219.

Rusch A, Valantin-M orison M, Sarthou J-P and Roger-Estrade J (2011) Multi-scale effects of landscape complexity and crop management on pollen beetle parasitism rate. Landsc Ecol 26:473-486. doi: 10.1007/s10980-011-9573-7

Scherr SJ and M cNeely JA (2008) Biodiversity conservation and agricultural sustainability: towards a new paradigm of "ecoagriculture"landscapes. Philos Trans R Soc B Biol Sci 363:477-494.

Segrestin B (2006) Innovation et coopération interentreprises: Comment gérer les partenariats d'exploration ? CNRS

Shai O, Reich Y, Hatchuel A and Subrahmanian E (2013) Creativity and scientific discovery with infused design and its analysis with C-K theory. Res Eng Des 24:201-214.

Simon H (1969) The Sciences of the Artificial. M IT Press, Cambridge

Soulignac V, Ermine J-L, Paris J-L, Devise $O$ and Chanet J-P (2012) A knowledge management system for exchanging and creating knowledge in organic farming. EJKM Electron J Knowl Manag 10:p-163.

Stockle CO, Donatelli M and Nelson R (2003) CropSyst, a cropping systems simulation model. EurJ Agron 18:289-307. doi: 10.1016/S1161-0301(02)00109-0

Suh NP (1999) A theory of complexity, periodicity and the design axioms. Res Eng Des 11:116-132. 
Suh NP (1990) The principles of design. Oxford University Press New York

Taylor PD, Fahrig L, Henein K and Merriam, G. (1993). Connectivity is a vital element of landscape structure. Oikos 68 (3), 571-573.

Toffolini Q, Jeuffroy M-H, Prost L (2016) Indicators used by farmers to design agricultural systems: a survey. Agron Sustain Dev 36:1-14.

Vereijken P (1997) A methodical way of prototyping integrated and ecological arable farming systems (I/EAFS) in interaction with pilot farms. Developments in Crop Science 25:293-308.

Walker DH, Thorne PJ, Sinclair FL, Thapa B, Wood CD and Subba DB (1999) A systems approach to comparing indigenous and scientific knowledge: consistency and discriminatory power of indigenous and laborato ry assessment of the nutritive value of tree fodder. Agric Syst 62:87-103.

Williams BK (2011) Adaptive management of natural resources-framework and issues.J Environ Manage 92:1346-1353. doi: 10.1016/j.jenvman.2010.10.041

Wolfe MS, Baresel JP, Desclaux D, Goldringer I, Hoad S, Kovacs G, Löschenberger F, M iedaner T, Østergård H and Bueren ETL van (2008) Developments in breeding cereals for organic agriculture. Euphytica 163:323-346. doi: 10.1007/s10681-0089690-9 